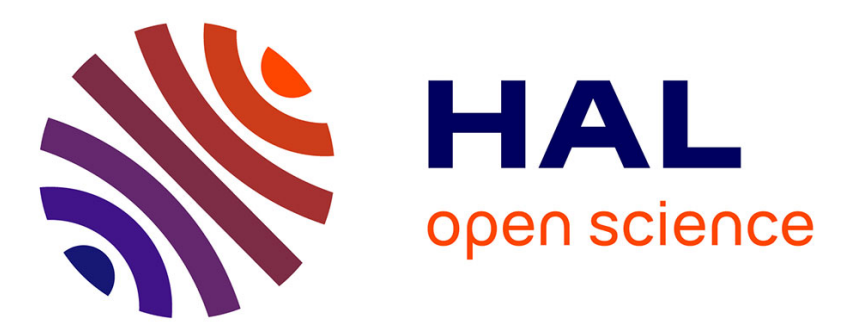

\title{
Thermophilic spore-forming bacteria isolated from spoiled canned food and their heat resistance. Results of a French ten-year survey
}

Stéphane André, François Zuber, Fabienne Remize

\section{To cite this version:}

Stéphane André, François Zuber, Fabienne Remize. Thermophilic spore-forming bacteria isolated from spoiled canned food and their heat resistance. Results of a French ten-year survey. International Journal of Food Microbiology, 2013, 165 (2), pp.134-143. 10.1016/j.ijfoodmicro.2013.04.019 . hal01201600

\section{HAL Id: hal-01201600 \\ https://hal.univ-reunion.fr/hal-01201600}

Submitted on 25 Sep 2017

HAL is a multi-disciplinary open access archive for the deposit and dissemination of scientific research documents, whether they are published or not. The documents may come from teaching and research institutions in France or abroad, or from public or private research centers.
L'archive ouverte pluridisciplinaire HAL, est destinée au dépôt et à la diffusion de documents scientifiques de niveau recherche, publiés ou non, émanant des établissements d'enseignement et de recherche français ou étrangers, des laboratoires publics ou privés. 
Thermophilic spore-forming bacteria isolated from spoiled canned food and their heat resistance.

\section{Results of a French ten-year survey.}

$\underline{\text { S. André }}^{*, 1}$, F. Zuber ${ }^{1}$, F. Remize $e^{1,2}$

${ }^{1}$ CTCPA Centre Technique de la Conservation des Produits Agricoles, Site Agroparc, ZA de l'Aéroport, BP 21 203, F-84 911 AVIGNON cedex 9, France.

${ }^{2}$ Present address: Laboratoire de Chimie des Substances Naturelles et Sciences des Aliments, ESIROI Agroalimentaire, Université de la Réunion, Parc Technologique Universitaire, 2 rue Joseph Wetzell, F97490 Sainte-Clotilde, France

Running title: Thermophilic spores from spoiled canned food

* Corresponding author: Stéphane ANDRÉ, CTCPA Centre Technique de la Conservation des Produits Agricoles, Site Agroparc, ZA de l'aéroport, BP 21 203, F-84 911 AVIGNON cedex 9, France. Tel +33 490 8417 09; Fax +33 4908417 26; email: sandre@ctcpa.org

\section{Highlights:}

- 455 samples of non-stable Low-Acid Canned Food (LACF) thah showed signs of spoilage after storage at $55^{\circ} \mathrm{C}$ from 122 canneries were collected over 10 years.

- From $93 \%$ of samples only one species was isolated.

- Two species, Moorella thermoacetica/thermoautotrophica and Geobacillus stearothermophilus, represented $69 \%$ of spoilage cases.

- Different hygienic indicators are proposed for different food categories. 


\section{Abstract}

Thermal processing of Low Acid Canned Foods (LACF), which are safe and shelf-stable at ambient temperature for several years, results in heat inactivation of all vegetative microorganisms and the partial or total inactivation of spores. Good Manufacturing Hygienic Practices include stability tests for managing the pathogen risk related to surviving mesophilic bacterial spores. LACF are also often submitted to additional incubation conditions, typically $55^{\circ} \mathrm{C}$ for 7 days, to monitor spoilage by thermophiles. In this study we identified the bacterial species responsible for non-stability after prolonged at $55^{\circ} \mathrm{C}$ incubation of LACF from 455 samples collected from 122 French canneries over 10 years.

Bacteria were identified by microsequencing or a recent developed tool for group-specific PCR detection (SporeTraQ ${ }^{\mathrm{TM}}$ ). A single species was identified for $93 \%$ of examined samples. Three genera were responsible for more than $80 \%$ of all non-stability cases: mostly Moorella (36\%) and Geobacillus (35\%), and less frequently Thermoanaerobacterium (10\%). The other most frequent bacterial genus identified were Bacillus, Thermoanaerobacter, Caldanaerobius, Anoxybacillus, Paenibacillus and Clostridium.

Species frequency was dependent on food category, i.e. vegetables, ready-made meals containing meat, seafood or other recipes, products containing fatty duck, and related to the intensity of the thermal treatment applied in these food categories. The spore heat resistance parameters ( $D$ or $\delta$ and $z$ values) from 36 strains isolated in this study were determined. Taken together, our results single out the species most suitable for use as indicators for thermal process settings. This extensively-documented survey of the species that cause non-stability at $55^{\circ} \mathrm{C}$ in LACF will help canneries to improve the management of microbial contamination.

Abbreviations: A.: Anoxybacillus, B.: Bacillus, Cr.: Caldanaerobacter, Ca.: Caldanaerobius, C.: Clostridium, Ge.: Gelria, G.: Geobacillus, M.: Moorella, P.: Paenibacillus, Th.: Thermoactinomyces, Tr.: Thermoanaerobacter, Tm.: Thermoanaerobacterium 


\section{Introduction}

Low Acid Canned Foods (LACF according to Codex Alimentarius, 1979) are thermally processed to ensure "commercial sterility" of the food product at ambient temperature for long-term storage. The biological stabilization process requires sufficient heat treatment, at temperatures above $100^{\circ} \mathrm{C}$ at every point of the container. This process results in the total inactivation of all vegetative bacteria and partial or total inactivation of spores. The pathogen risk related to surviving of mesophilic bacterial spores is managed according to Good Manufacturing Hygienic Practice guidelines (Codex Alimentarius, 1979, CTCPA, 2012a; CTCPA, 2012b). In addition, stability tests involving food container incubation are widely used to detect the possible development of surviving spores. The Codex Alimentarius recommends that food containers should be incubated for 10 or 14 days at $37^{\circ} \mathrm{C}$ (Codex Alimentarius, 1979). Under French standards NF V08-401 (Afnor, 1997a) and NF V08-408 (Afnor, 1997b), samples are incubated at $37^{\circ} \mathrm{C}$ for 7 days or $32^{\circ} \mathrm{C}$ for 21 days. It has been shown that these conditions allow surviving mesophilic spores to germinate and grow in the canned food. Spoilage resulting from microbial growth is then detected by gas production (container swelling), abnormal odours/colours or $\mathrm{pH}$ variation, and possibly microscopy examination. If samples test positive, the canned food batch is destroyed to prevent food safety issues. Industrial canning industry processes are consequently designed to reach sterilization values $\left(F_{0}\right.$, min) that ensure "commercial sterility" and therefore microbiological food safety.

The simulation of excessive temperature conditions during storage (transport and retail, especially in relation to exports to the countries with high ambiant temperatures) uses other incubation conditions to test canned food stability, typically $55^{\circ} \mathrm{C}$ for different durations according countries guidelines. Although thermophilic spore-forming bacteria are not described as pathogenic, their presence may impair the commercial viability of products stored at high ambient temperatures. In addition, LACF non-stability detected after prolonged $55^{\circ} \mathrm{C}$ incubation reflects insufficient control of hygiene during the end-to-end food processing chain, mainly due to: i) insufficient heat treatment and/or ii) the presence of highly heatresistant spores on processing lines and raw materials, even at low concentrations.

Therefore, global hygiene management on industrial-line processes essentially relies on surveys of the thermophilic spores that contaminate food before the can sterilization step. Consequently the canning industry needs better knowledge of thermophilic spore-forming bacteria and their origin on processing lines in order to ensure better process control of hygiene conditions.

Only a handful of now outdated studies have addressed the identification and occurrence of sporeforming bacteria responsible for canned food spoilage (Richardson, 1972; Pflug et al., 1981; Matsuda et al., 1985b), and most of these studies remained limited to a single product category (Vicini, 1986) or a 
single group of microorganisms (Matsuda et al., 1985a; Dotzauer et al., 2002). Taxonomy has since evolved to integrate new species definitions, and strain isolation and identification techniques have made great strides forward. The aims of this study were: i) to identify the bacterial species responsible for spoilage in $55^{\circ} \mathrm{C}$-incubated LACF and ii) to bring insight on the possible causes of canned food nonstability and the species present in spoiled products. The species detected were characterized to help develop better monitoring protocols and detect emerging and/or poorly described species. Spoiled canned food samples were collected in France over a ten-year period.

\section{Material and methods}

\subsection{Sampling}

From 2001 to 2010, French canners sent samples of spoiled LACF detected after incubation tests performed at $55^{\circ} \mathrm{C}$ to the CTCPA (French Technical Center for the Preservation of Agricultural Products) for laboratory analysis in order to isolate and identify the microorganisms present in the cans.

Samples were grouped into three recipe categories: vegetables (21 different recipes); ready-made meals containing essentially meat (15 different recipes), seafood (6 different recipes) or other courses (7 different recipes); products containing fatty duck (two different recipes). The heat treatments used for the canned food were grouped into three categories : low-heat treatments levels with a Fo of less than 5 min ; moderate-heat treatments levels with Fo values between 5 and $20 \mathrm{~min}$; and high-heat treatments levels with a Fo of over $20 \mathrm{~min}$.

Samples were detected spoiled after incubation at $55^{\circ} \mathrm{C}$ for 7 days as proposed by French standard NF V08-408 (Afnor, 1997b). According to this standard, non-stability is primarily detected by a change in packaging aspect. After aseptically opening the container, the odor and appearance of the food product were recorded and $\mathrm{pH}$ was determined to detect variation between $55^{\circ} \mathrm{C}$-incubated samples and room temperature-incubated controls. Microscopy analysis was performed if required.

\subsection{Culture of bacteria}

AFNOR-CNERNA guidelines were used to revivify viable bacteria from spoiled products (Bouvier et al., 1982) by homogenizing $10 \mathrm{~g}$ samples with an $90 \mathrm{ml}$ of peptone water (AES Chemunex, Ivry-sur-Seine, France) in a stomacher for $1 \mathrm{~min}$. Around $10 \mathrm{~mL}$ of the stomacher bag filtrate were collected into a glass tube and treated at $10 \mathrm{~min}$ at $100^{\circ} \mathrm{C}$ in a water bath was applied to select heat-resistant spores by killing all vegetatives cells and favoring spore germination. Both non-heated and heated $1 \mathrm{~mL}$-homogenized- 
and-filtered samples were used to inoculate broths described in Bouvier et al. (1982). Incubation lasted 7 days at $37^{\circ} \mathrm{C}$ or $55^{\circ} \mathrm{C}$ and aerobically or anaerobically by the use of a paraffin stopper.

For isolation, bacterial cultures were plated on dextrose tryptone agar or meat-liver glucose agar (Biokar, Beauvais, France) and incubated at the same temperature and atmosphere as the earlier liquid culture. The same culture conditions were used for enumeration using decimal dilution method.

\subsection{DNA preparation}

A colony was suspended in $100 \mu \mathrm{L}$ of sterile water, or $1 \mathrm{~mL}$ of broth culture was centrifugated $(13000 \times \mathrm{g}$ for $5 \mathrm{~min}$ ), washed in sterile water, centrifigated again (13000 $\times \mathrm{g}$ for $5 \mathrm{~min}$ ) and suspended in $100 \mu \mathrm{L}$ of sterile water. And the InstaGene ${ }^{\circledR}$ lysis system according to the manufacturer's instructions (Bio-Rad, Marnes-la-Coquette, France) was used to extract DNA.

\section{$1.4 P C R$ detection of specific bacterial group (SporeTraQ ${ }^{\mathrm{TM}}$ )}

Geobacillus stearothermophilus, Moorella thermoacetica/thermoautotrophica and Thermoanaerobacterium spp group were screened by PCR assay according to Prevost et al. (2010) after bacterial growth followed revivification performed at $55^{\circ} \mathrm{C}$. The reverse primer sequence for M. thermoacetica/thermoautotrophica detection was modified to AGGCTATTCGCCTTTAAGAC (Sevenier et al., 2012). All amplifications were performed in a GeneAmp 9700 PCR system (Applied Biosystems, Courtaboeuf, France).

\section{$1.5 \quad$ Identification of bacteria}

Identification involved partial sequencing of the $16 \mathrm{~S}$ rRNA coding region. For this, PCR was performed with primers FD1 and RD1 according to Weisburg et al. (1991). The amplicon was column-purified before sequencing. Sequencing was performed by Eurofins MWG Operon (Ebersberg, Germany) according to Sanger's method. The primers used for sequencing were S6-16S (GTATTACCGCGGCTGCTG) and/or FD1. Longer sequences were obtained for Thermoanaerobacterium isolates with a second sequencing primer CCCCACCTTCCTCCGTG. Sequences were checked for quality and further compared against nucleotide databases (GenBank at NCBI) using MEGABLAST with RDP software (Cole et al., 2009). 16S rRNA coding sequences of $0.9 \mathrm{~kb}$ minimal length from isolated thermophilic anaerobes were used for sequence analysis and registered in GenBank under accession numbers JX984955 to JX984980. Typestrain sequences from the RDP database corresponded to: Caldanaerobacter subterraneus AE012979 (1527 bp), Cr. subterraneus AF212925 (1501 bp), Caldanaerobius fijiensis EF507903 (1354 bp), Cs. 
polysaccharolyticus U40229 (1360 bp), Cs. zeae U75993 (1449 bp), Gelria glutamica AF321086 (1725 bp), Moorella glycerini U82327 (1513 bp), M. thermoacetica AY656675 (1430 bp), M. thermoautotrophica L09168 (1553 bp), Tr. brockii L09165 (1513 bp), Tr. brockii L09166 (1523 bp), Tr. brockii U14330 (1507 bp), Tr. ethanolicus L09162 (1740 bp), Tr. italicus AJ250846 (1480 bp), Tr. mathranii AY701758 (1404 bp), Tr. mathranii Y11279 (1507 bp), Tr. pseudethanolicus L09164 (1515 bp), Tr. siderophilus AF120479 (1561 bp), Tr. sulfurigignens AF234164 (1501 bp), Tr. thermocopriae L09167 (1522 bp), Tr. uzonensis EF530067 (1415 bp), Tr. wiegelii X92513 (1464 bp), Tm aciditolerans AY350594 (1442 bp), Tm. aotearoense X93359 (1478 bp), Tm. saccharolyticum L09169 1552 bp), Tm. thermosaccharolyticum AF247003 (1452 bp), Tm. thermosaccharolyticum EU563362 (1509 bp), Tm. thermosaccharolyticum CP002171 (1504 bp), Tm. thermosaccharolyticum HM585225 (1457bp), Thermoanaerobacterium thermosulfurigenes L09171 1574 bp), Tm. xylanolyticum L09172, Thermodesulfobium narugense AB077817 (1363 bp).

These sequences were aligned using the CLUSTAL Omega program at EBI (Goujon et al., 2010). A dendrogram was built by the average distance method using percent identity on JalView software (Waterhouse et al., 2009). Distance expresses the average relative level of divergence between two aligned sequences. On the tree, branch lengths represent distances.

\subsection{Spore suspensions}

Thirty eight spores suspensions obtained with 36 strains were prepared according to French standard method NF T 72-231 (Afnor, 1988). Cell suspension (5 ml) following incubation at optimal temperature was inoculated onto agar media ( $140 \mathrm{~mm}$ diameter plate). Aerobic bacteria medium consisted of $10 \mathrm{~g}$ of beef extract, $2 \mathrm{~g}$ of yeast extract, $0.04 \mathrm{~g}$ of $\mathrm{MnSO} 4 \mathrm{H} 2 \mathrm{O}$, and $15 \mathrm{~g}$ of agar in 1 liter. Anaerobic bacteria medium consisted of $30 \mathrm{~g}$ of tryptone, $5 \mathrm{~g}$ of glucose, $20 \mathrm{~g}$ of yeast extract, $1 \mathrm{~g}$ of sodium thioglycolate, and $15 \mathrm{~g}$ of agar in 1 liter. Incubation was performed either 37 or $55^{\circ} \mathrm{C}$ depending on species and prolonged for 2 to 5 days for aerobic bacteria and 3 to 4 weeks under anaerobic conditions for others. Durations were ajusted by survey of percentage of spores, determined by microscopy observation. When $90 \%$ of spores were observed, harvest was decided. For meso-thermophilic species, optimal sporulation temperature was set by the highest quantity of spores obtained. For 2 strains (B. coagulans and $B$. smithii), the both temperatures were used. Spores were harvested by adding cold sterile distilled water onto agar and transferred into a sterile centrifugation tube. The spore suspension was centrifuged at 4000 $x g$ for $20 \mathrm{~min}$ at $4^{\circ} \mathrm{C}$ and the pellet was washed three times following the same protocol, resuspended in $20 \mathrm{~mL}$ sterile distilled water, heat-treated, then stored at $4^{\circ} \mathrm{C}$ until analysis. Heat treatment was performed 
in a water bath for $10 \mathrm{~min}$ at $80^{\circ} \mathrm{C}$ for Clostridium and strict-mesophilic Bacillus spp and Paenibacillus spp isolates and for $10 \mathrm{~min}$ at $100^{\circ} \mathrm{C}$ for other Bacillus spp, Geobacillus stearothermophilus, Moorella thermoacetica/thermoautotrophica, Thermoanaerobacter pseudothanolicus and Thermoanaerobacterium $\mathrm{sp}$ strains. The concentrated heat-treated suspensions exhibited up to $10^{8} \mathrm{spores} / \mathrm{mL}$, except for Moorella, Thermoanaerobacter and Thermoanaerobacterium sp. For the latter, spore suspension contained between $10^{6}$ and $10^{7}$ spores $/ \mathrm{mL}$.

\subsection{Heat resistance of spore suspensions}

$100 \mu \mathrm{L}$ capillary tubes (Ringcaps ${ }^{\circledR}$ Duran $($ ) were filled with $50 \mu \mathrm{L}$ of spore suspension in $0.2 \mathrm{M}$ phosphate buffer $\mathrm{pH} 7$. Spores were heat-treated in a thermostated oil bath at temperatures ranging from $82^{\circ} \mathrm{C}$ to $132^{\circ} \mathrm{C}$. For each spore suspension, heat resistance was evaluated on a temperature range of 9 to $13^{\circ} \mathrm{C}$ over a time range of 30 seconds to 6 hours. After heating, the tubes were immediately cooled in water. Then each end was opened aseptically and the suspension was flushed out with $3 \mathrm{~mL}$ of sterile tryptone-salt broth (AES Chemunex, Ivry-sur-Seine, France). Culturable cells were counted as described above. D values were estimated from linear portions of the log plots of surviving population vs heating time. $\bar{\delta}$ and $p$ values were calculated according to the Weibull model modified by Mafart et al. (2002) in which $\delta$ is the first reduction time that leads to a 10 -fold reduction in surviving population, and $p$ is the shape parameter. $\mathbf{z}$ values were determined by plotting $D$ or $\bar{\delta}$ values vs temperature.

\subsection{Statistical analysis}

Statistical analysis was performed using XLSTAT software (AddinsoftTM, Paris, France). The correlation between the two heat resistance modeling methods was evaluated with a Pearson test. All tests were interpreted with a p-value of 0.05 (Tukey's honestly significant difference test).

\section{Results and discussion}

\subsection{Each spoilage case is mainly associated to a single species}

A total of 455 samples of various recipes from 122 factories were collected over the course of this 10 -year survey. An average of 26 vegetables, 17 ready-made meals and 5 samples containing fatty duck were examined each year.

During first years of study then several times during last years, several isolates were collected after enrichment from spoiled samples. Finally, in 99 spoiled samples, 2 to 5 differents isolates were identified 
(Table 1). These 99 samples, whith several identifications, among 462 cases, were representative of the food category variety [vegetables ( $55 \%$ of 99 selected samples and $56 \%$ of the 462 samples collection), ready-made meals containing meat $(27 \%$ and $24 \%)$, ready-made meals containing seafood ( $3 \%$ and $3 \%)$ or other ready-made meal recipes $(7 \%$ and $10 \%)$, and products containing fatty duck $(8 \%$ and $7 \%)]$. A single species was identified for $93 \%$ of these samples. This observation is consistent with the observation that $10 \%$ of samples in which bacterial DNA was directly extracted from spoiled food resulted in two mixed sequences on chromatogram (personal communication). For the 7 other samples in which different species were observed, only two species were found: Geobacillus was found with either Thermoanaerobacterium or Bacillus, while Thermoanaerobacterium was found with Moorella or Thermoanaerobacter. For analysis of the identification results, the 7 samples containing two identified species were considered as 14 different identifications. Taking into account the high percentage of samples with a single species identified, a single identification was performed for all other samples examined either if two different isolates were clarely detected.

For the five food categories, i.e. vegetables, ready-made meals based on meat, ready-made meals based on seafood, or other ready-made meal recipes, and products containing fatty duck, isolation resulted, respectively, in 258 (55\%), $112(24 \%), 15(4 \%), 46$ (10\%) and 31 (7\%) different identifications (Table 2). Thus, a total of 462 different identifications were considered in this study.

\subsection{Phylogenic relationship between canned-food isolated Thermoanaerobacterium sp. type}

Thermoanaerobacterium species and other thermophilic anaerobic sporeformers

A large fraction of the thermophilic anaerobes identified in this study belong to phylogenetic groups that were only recently described. Thus we analyzed the $16 S$ rRNA gene sequences to investigate how the 29 isolates obtained here and labeled were related to previously-described Thermoanaerobacterales. This order gathers Thermoanaerobacterium (Liu et al, 1996; Can et al, 2001; Klubanov et al, 2007), Thermoanaerobacter (Fardeau et al, 2004; Carlier et al, 2006), Caldanaerobius (Lee et al, 2008), Caldanaerobacter (Fardeau et al, 2004), Moorella (Pierce et al, 2008) and Gelria (Plugge et al, 2002). We collected 32 sequences of type species and type strains from databases to anchor our analysis with (accession numbers starting by JX or as CTT). The percent of identity between each pair of sequence aligned varies between $36 \%$ and $100 \%$.

As expected, the obtained phylogenic tree exhibited clusters corresponding to the different genera (Figure

1). Six branches differed by a distance greater than 4 . The strain Thermodesulfobium narugense clustered independently and was marked branch A. One group, labeled B, corresponded to 
Thermoanaerobacter and Caldanaerobacter. The genus Moorella was clearly separated into a branch labeled C. Two other clusters gathered the Gelria genus on one side (group D) and Caldanaerobius on the other (group E). The Thermoanaerobacterium group was independently clustered in a branch labeled F.

A strain referenced JX984955 originally identified from a partial 16S rRNA gene sequence as Gelria glutamica was the closest relative of the type strain, although at a distance of 0.44 . Similarly, the isolates JX984962, JX984963 and JX984964 were clearly related to $M$. thermoacetica/M. thermoautotrophica type strains and separated from the species M. glycerini by a distance of 2.31. Four isolates, JX984972, JX984980, JX984966 and CTT4, were gatherable with the species Ca. polysaccharolyticus and Ca. fijiensis and were more distant to $\mathrm{Ca}$. zeae. These isolates were identified as $\mathrm{Ca}$. polysaccharolyticus.

The isolates identified as Thermoanaerobacterium spp were partly separated. One cluster, labeled F1, exhibiting a maximal distance between all isolates of less than 0.96 gathered the species $\mathrm{Tm}$. aotearoense Tm. aciditolerans and Tm. thermosaccharolyticum. However, within this cluster, three subgroups could be distinguished. An isolate named JX984977 that was related to this group but clustered individually was identified as Thermoanaerobacterium sp. A first subgroup was related to the reference strain Tm. aotearoense X93359. It gathered the isolates CTT5, JX984960, JX984975, JX984967, JX984969, JX984965 and JX984959. These isolates were then classified as Tm. aotearoense. Another cluster corresponding to isolates JX984961, JX984957 and JX984970 was related to Tm. Aciditolerans type strain. A second subgroup clustering the isolates JX984956, JX984978, JX984979, JX984976, JX984958, JX984974, JX984971 and JX984968 was closely related to the Tm. aciditolerans type strain. Lastly, a cluster labeled F2, gathered isolates CTT3 and JX984973 with Tm. saccharolyticum at a distance of 1.11 from Tm. thermosulfurigenes and Tm. xylanolyticum.

\subsection{Patterns of the bacterial species involved in high-temperature spoilage of canned food}

Only two genera gathered $71 \%$ of bacteria identified from $55^{\circ} \mathrm{C}$ spoiled canned food samples. Moorella and Geobacillus were found respectively in $36 \%$ and $35 \%$ of samples (Table 2). Strikingly, these two genera were mainly represented by a single species: G. stearothermophilus represented $94 \%$ of Geobacillus spp and M. thermoacetica / thermoautotrophica $100 \%$ of Moorella spp. M. thermoacetica is an anaerobic sporeformer described as highly resistant to heat (Ashton and Bernard, 1992; Wagner and Wiegel, 2008). Its growth in canned food is reported to result in strong acidification and can swelling (Ashton et al., 1992; Olson and Sorrells, 1992). Its optimal growth temperature is $55-60^{\circ} \mathrm{C}$ and it is considered as a model acetogen (Drake and Daniel, 2004). G. stearothermophilus is typically described 
as responsible for flat sour can spoilage (Olson et al., 1992; Moir et al., 2001; Tucker and Featherstone, 2011). The optimal growth temperature of the Geobacillus group is $55-65^{\circ} \mathrm{C}$ (Nazina et al., 2001).

Thermoanaerobacterium spp was identified in $8 \%$ of spoiled canned food samples. It shares similar physiological characteristics, such as anaerobic growth and an optimal growth temperature of around $63^{\circ} \mathrm{C}$, to $M$. thermoacetica. Except for the species $\mathrm{Tm}$. thermosaccharolyticum (formerly Clostridium thermosaccharolyticum), the other species were not previously described in food (Ashton et al., 1992; Chapman, 2001).

Bacillus spp was identified in $9 \%$ of spoiled samples. B. coagulans was the most frequent of the 7 different Bacillus species observed, while B. smithii and B. licheniformis were the two other species frequently detected. B. coagulans is commonly involved in the spoilage of moderately-acid canned vegetables like tomato products (Thompson, 1981; Hanlin, 1998; Moir et al., 2001; Tucker and Featherstone, 2011) and in other canned vegetables (Matsuda et al., 1985a; Oomes et al., 2007), and is acid-tolerant. B. licheniformis is often isolated in spoiled canned food (Anatskaya and Efimova, 1978; Chang and Lee, 1982; Matsuda et al., 1985b) and in the dairy industry (Anatskaya et al., 1978; Hanlin, 1998; Scheldeman et al., 2005), whereas $B$. smithii had never previously been isolated from canned food and only once in food (Röling et al., 2001).

Other individual genera represented less than $5 \%$ of spoilage cases. The lowest frequencies of detection corresponded to Caldanaerobius spp, Gelria glutamica, Anoxybacillus spp, Paenibacillus spp, Thermoanaerobacter spp, Clostridium thermopalmarium/thermobutyricum, Thermoactinomyces sp and several species of Geobacillus other than stearothermophilus. To our knowledge, Caldanaerobius spp and Gelria glutamica have never been previously described as canned food contaminants. Anoxybacillus contaminans has been described in food gelatin batches (De Clerck et al., 2004) while Anoxybacillus flavithermus has been described in heat-processed dairy products and biofilms from food processing environments (Rueckert et al., 2005; Burgess et al., 2009; Postollec et al., 2012). Paenibacillus species are routinely found in low-acid canned products or dairy products (Anatskaya et al., 1978; Casadei et al., 2000). Several species of Thermoanaerobacter were identified from hot environments (Wagner et al., 2008). The biochemical characteristics and phylogenetic relationship of Thermoanaerobacter isolates from canning factories was investigated by Carlier and Bedora-Faure (2006) who proposed a new subspecies, Thermoanaerobacter mathranii subsp. alimentarius. Clostridium thermopalmarium/thermobutyricum was the only Clostridium species identified in our study. $\mathrm{Cl}$. thermopalmarium, originally described from palm wine in Senegal (Soh et al., 1991), is moderately thermophilic with an optimal growth temperature of $50-55^{\circ} \mathrm{C}$. It is genetically close to $\mathrm{Cl}$. thermobutyricum, 
but with distinct physiological traits (Wiegel et al., 1981). This species was identified exclusively in products containing fatty duck. It represented the main bacterium involved in this spoilage food category and was never isolated in other food categories.

The origin of thermophilic anaerobes like Moorella spp, Thermoanaerobacterium spp and Thermoanaerobacter spp, which caused more than half of can spoilage cases in our study, is usually hot environments like geothermal hot springs and hydrothermal vents or sometimes warm environments like compost and manure (Wagner et al., 2008). For Presland et al. (2004), only Geobacillus and Bacillus aerobic bacteria and Moorella anaerobic sporeformers were cited as thermophiles involved in canned food spoilage. M. thermoacetica has occasionally been isolated in canned vegetables (Carlier et al., 2006) or in specific spoiled food products such as canned coffee and "shiruko" (Matsuda et al., 1982). Dotzauer et al., (2002) identified Thermoanaerobacterium and Thermoanaerobacter and not Moorella, but the occurrence of the different genera in their thermophilic anaerobes groups contrasts with our results. It could be due to their agar medium on which isolates from this genus was unable to grow. We consider especially difficult to isolate these genus because it requires special agar not used in bibliography and long duration of incubation rarely used for spore forming bacteria culture. In addition, the genus Desulfutomaculum was not isolated in our study whereas it was described as a spoilage bacterium of canned foods, such as spoiled canned milk-containing 'shiruko' coffee or low-acid canned vegetables such as sweet corn (Matsuda et al., 1982; Chapman, 2001; Sperber and Doyle 2009).

\subsection{Food category breakdown of the occurrence of the main bacterial groups}

Differences in the patterns of identified isolates according to product category were observed (Table 3 ). In spoiled vegetables and ready-made meals, the same dominant species, G. stearothermophilus and $M$. thermoacetica/thermoautotrophica, were identified. This correlation between vegetables and ready-made meals could be due to the contribution of vegetables and other plant-based ingredients such as spices which are frequent sources of contamination (Bolton, 2001; Witkowska et al., 2011). This predominance of both species was not observed in the products containing fatty duck, in which the main spoilage species were Thermoanaerobacterium and Clostridium thermopalmarium/thermobutyricum. This difference could be related to the product category (presence of high concentrations of lipids that could be limiting for spore germination (Dallyn and Everton, 1970; Lekogo et al., 2010)) or to a low level of thermal treatments (products containing fatty duck present $F_{0}$ values lower than $5 \mathrm{~min}$; Table 3). The raw materials used were also very different (only fatty liver or duck meat and fat), although spices (usually black pepper) could be a source of the same bacterial species as in vegetables and ready-made meals. 
The other main species detected were Thermoanaerobacterium spp and Bacillus spp. The species distribution is similar between the five food categories, with $\mathrm{Tm}$. thermosaccharolyticum one of the most represented within the genus. Dotzauer et al. (2002) observed a similar species distribution, with few Thermoanaerobacterium sp and a majority of $\mathrm{Tm}$. thermosaccharolyticum.

A deeper analysis was made of the relationship between spoiled canned food products and the bacteria identified by considering recipe and $F_{0}$ for each product category (Table 3).

In vegetable-based spoiled canned food, G. stearothermophilus was isolated from 18 out of 22 different recipes, whereas $M$. thermoaceticalthermoautotrophica was isolated from 11 different recipes. $M$. thermoacetica/thermoautotrophica was mainly identified from green peas ( $40 \%$ of Moorella spoilage cases) and green peas with carrots (22\% of Moorella spoilage cases). Moorella represented more than two thirds of spoilage bacteria identified from these products. In other vegetable-based recipes, $M$. thermoacetica/thermoautotrophica was frequently detected in mushrooms, green beans, spinach and mixed vegetables. G. stearothermophilus spoilage was widespread among the different recipes: 11 vegetable-based recipes resulted in at least four $(4.5 \%)$ independent detections of the bacterium. The recipes that most frequently led to $G$. stearothermophilus development were mixed vegetables, followed by green beans, green peas, and then sweet corn. Green beans, green peas and sweet corn are the leading canned vegetables by volume produced in France (Bernardin et al., 2010). However, G. stearothermophilus alone accounted for more than $40 \%$ of spoilage cases of green beans and more than $80 \%$ of spoilage cases of sweet corn. As $G$. stearothermophilus was found in various recipes containing a single vegetable, it was logically also found in mixes of these products. G. stearothermophilus was isolated from canned peas by Georgescu and Bugulescu (1969), from spoiled canned tomatoes by Hernandez and Feria (1971), and from spoiled canned green beans by Baumgart et al. (1983). For other bacteria identified from spoiled vegetable-based canned food, we found no clear distribution pattern according to recipe, except that $A$. contaminans was identified exclusively in soups.

In meat-based ready-made meals, the difference between recipe distribution of spoilage caused by $M$. thermoaceticalthermoautotrophica or G. stearothermophilus was less marked than in vegetables. $G$. stearothermophilus was mainly found in meat-based recipes and cassoulet, while $M$. thermoacetica/thermoautotrophica was mainly found in poultry recipes, sausages-and-lentils, and cottage pie. Its presence in cottage pie may be due to $M$. thermoaceticalthermoautotrophica contamination of the heavily processed potatoes flakes widely used for industrial mashed potato preparation. However, the high frequency of $M$. thermoacetica/thermoautotrophica in the sausages-and-lentils recipe could not be directly related to lentil contamination, as we found no cases of caused $M$. 
thermoacetica/thermoautotrophica spoilage of lentils in brine. For other bacteria detected as spoilage agents of ready-made canned meals, the only salient feature was $B$. coagulans mainly identified in cassoulet. G. stearothermophilus was again the most widespread species. In other ready-made meals as well as in quenelles and dairy dessert recipes. G. stearothermophilus was often incriminated in the contamination of powdered milk and dehydrated ingredients (Rueckert et al., 2005; Postollec et al., 2012). Lastly, A. flavothermus was exclusively identified from spoiled fish soup.

In products containing fatty duck, Thermoanaerobacterium sp was found mainly in foie gras and in fatpreserved duck, whereas $C$. thermopalmarium/thermobutyricum was only found in foie gras.

Based on this analysis, several bacterial groups of spore-formers could thus be singled out as candidate for spoilage indicators in different food categories, in ordrer to establish microbial criteria or minimum processing parameters. These indicators depend on both the ingredients used and the level of heat treatment applied. For canned vegetables and meat-based ready-made meals heat-treated according to traditional process with $F_{0}$ values above 20 min, the general indicators are $G$. stearothermophilus and $M$. thermoacetica/thermoautotrophica. M. thermoacetica/thermoautotrophica emerges as a specifically relevant indicator for vegetable mixes containing peas containing, while $G$. stearothermophilus is specific to dairy-derived products. Anoxybacillus spp is relevant for soups, and to a lesser extent $B$. coagulans is relevant for cassoulet and foie gras. For products containing fatty duck that are treated with $F_{0}$ values below $5 \mathrm{~min}$, both Thermoanaerobacterium sp and $C$. thermopalmarium thermobutyricum are the most suitable hygienic indicators.

\section{$2.5 \quad$ Heat resistance parameters}

Heat resistance parameters were determined on spore suspensions in order to investigate prospective relationships between spoilage bacteria spore heat resistance and the level of heat treatment applied for product stabilization (Table 4). Standardized conditions were required to compare heat-resistance levels between strains. As most heat destruction kinetics were not log-linear, the Weibull model was used (Mafart et al., 2002). However, as $\mathbf{z}_{\text {Weibull }}$ values were not significantly different to $\mathbf{z}_{\text {loglinear }}$ values (Pearson test, $p<0.0001$ ), we used $D$ values to compare species according to their heat resistance, as $D$ values are a virtual worldwide industry standard whereas Weibull model parameters ( $\delta$ and $p$ values) are rarely employed. The stability of $\mathbf{z}$ values, which are $\mathrm{pH}$ and sporulation temperature-independent, was reported by Baril et al. (2012). The indicator species were tested and other mesophilic species were added to expand the overview. 
As expected, $M$. thermoacetica/thermoautotrophica was the species exhibiting the highest heat resistance, with $\mathrm{D}$ values at $122^{\circ} \mathrm{C}$ up to $30 \mathrm{~min}$ for the three strains tested. Similar results were reported by Byrer et al. (2000) and Mastuda et al. (1982). D values at $121^{\circ} \mathrm{C}$ obtained for $\mathrm{G}$. stearothermophilus corresponded to a few minutes, as usually reported (Bender and Marquis, 1985; Ocio et al., 1996). values were slightly higher for Thermoanaerobacterium than $G$. stearothermophilus but still far less than for $M$. thermoacetica/thermoautotrophica. The $\mathrm{D}$ values of Thermoanaerobacterium isolates were below those reported by Xezones et al. (1965) who found D values at $121^{\circ} \mathrm{C}$ up to $50 \mathrm{~min}$.

Contrary to thermophilic strains, all mesophilic strains exhibited $D$ values of $10 \mathrm{~min}$ at temperatures below $108^{\circ} \mathrm{C}$. This was expected, as mesophiles are often described as less heat-resistant than thermophiles (Sperber and Doyle 2009). The two meso-thermophilic strains that were sporulated either at $37^{\circ} \mathrm{C}$ or at $55^{\circ} \mathrm{C}$ (B. licheniformis 3107043 and B. smithii 3108 003) exhibited a slightly higher heat resistance for spores produced at $55^{\circ} \mathrm{C}$ than at $37^{\circ} \mathrm{C}$. Leguerinel et al. (2007) and Sala et al. (1997) demonstrated a high impact of sporulation conditions on heat resistance that could partly explain this observation. However, this relationship between spore resistance and sporulation temperature was modulated by the strain used, as different strains of $B$. licheniformis and $B$. smithii, Thermoanaerobacterium $\mathrm{sp}$ and $B$. coagulans able to grow at both $37^{\circ} \mathrm{C}$ and $55^{\circ} \mathrm{C}$ displayed the most variable $\mathrm{D}$ values. Relationship between growth temperature range and spore heat resistance range was found: mesophilic strains were less heat resistant than thermophilic ones. And among the thermophilic species, extreme thermophiles were more heat resistant than others. For these meso-thermophilic species, $D$ values of 10 min were observed on a temperature range of $8^{\circ} \mathrm{C}$ wide, while temperature range did not exceed $2^{\circ} \mathrm{C}$ for the other either strict mesophilic or thermophilic species.

The literature reports $z$ values comprised between 6 and $12^{\circ} \mathrm{C}$ whatever the species (Stumbo, 1973; Jenson and Jensen, 2001; Tucker and Featherstone, 2011). In our study, $\mathbf{z}$ values were in this range and all values were below $10^{\circ} \mathrm{C}$. Note that strict anaerobic thermophiles exhibited the lowest values as observed by Jenson and Jensen (2001).

As expected, the canned-food $\mathrm{F}_{0}$-value observed in industry was strongly related to heat resistance of the strains isolated. The most heat-resistant species, $M$. thermoacetica/thermoautotrophica, was isolated from canned products treated at $F_{0}>20 \mathrm{~min}$. $G$. stearothermophilus was regularly isolated from products treated at moderate or high heat levels ( $F_{0}$ between 5 to $20 \mathrm{~min}$ and $F_{0}$ above $20 \mathrm{~min}$ ). The isolation conditions of $B$. coagulans strains proved the most significant, yielding a strict correlation between heat resistance level and $F_{0}$-value applied to the canned products. The less heat-resistant strain (3105 044$)$ was isolated from a pasteurization process, the next-least-heat-resistant strain (3105 018) from a canned 
foie gras (Fo $<5 \mathrm{~min}$ ) and the third least-heat-resistant strain (3105 018) from a cassoulet treated at $5<$ Fo $<20 \mathrm{~min}$.

However, our data do not explain why M. thermoacetica/thermoautotrophica was not isolated from spoiled products that were treated at $\mathrm{F}_{0}$-values too low to inactivate its spores. The most realistic hypothesis is that the low growth rate of this species favors competiting bacteria that were faster to spoil the product as they were not destroyed by the low-level heat treatment.

\section{Conclusion}

This paper reports results from a long-term ten-year survey of the causes of food spoilage in hightemperate heat-treated canned foods in France. With these 462 isolates from spoiled canned food of 122 canneries, the study enriches previous data on species isolated from spoiled LACF products (Landry et al., 2001; Tucker and Featherstone, 2011). The spoilage bacteria involved are highly heat-resistant, thermophilic and non-pathogenic with 2 species representing $69 \%$ of spoilage cases. Our results confirmed that thermophilic bacteria are good indicators of food hygiene, as highlighted by Burgess (Burgess et al., 2010). Adapted bacterial indicator groups for canned food spoilage were proposed. These data and more specifically the heat resistance parameters determined for strains isolated from industrial food processes, bring valuable insights for the management of processing line contamination and for the calculation of scheduled sterilization heat treatments. Screening for these indicators in raw materials, ingredients and samples from processing lines could help single out several contamination locations in canneries for a better hygiene control.

Better control of thermophilic spores by proper cleaning of processing lines and higher standards of quality for raw materials and the determination of the elevated-temperature stability of LACF should help improve food safety monitoring: any increase in $55^{\circ} \mathrm{C}$-non-stability frequency should therefore be considered as a warning sign that hygiene conditions on processing lines are degraded for either thermophilic spoilage and mesophilic pathogen spore forming bacteria. In this purpose, it should be necessary to determine precisely the process steps where these species proliferated and to know the genetic and physiologic diversity of strains to link raw material, multiplication area and spoiled products.

\section{Acknowledgments}

This work was supported by FranceAgriMer. We thank the French canned food manufacturers that kindly collected the spoiled samples. 


\section{Bibliography}

Afnor. 1988. Détermination de l'activité sporicide - Méthode par filtration sur membranes., Antiseptiques et désinfectants utilisés à l'état liquide, miscibles à l'eau, NF T72-231. Afnor, Paris.

Afnor. 1997a. Contrôle de la stabilité des produits appertisés et assimilés - Méthode de référence, Microbiologie des aliments, NF V08-401. Afnor, Paris.

Afnor. 1997b. Contrôle de la stabilité des produits appertisés et assimilés - Méthode de routine, Microbiologie des aliments, NF V08-408. Afnor, Paris.

Anatskaya, A.G., Efimova, V.A., 1978. Spoilage of evaporated sterilized milk by sporeforming bacteria. XX International Dairy Congress, 739-740.

Ashton, D., Bernard, D., 1992. Thermophilic anaerobic sporeformers. In: Vanderzantz, C., Splittstoesser, D.F., (Eds.), Compendium of methods for the microbiological examination of foods, 3rd Edition. American Public Health Association, Washington, D.C. 309-316.

Baril, E., Coroller, L., Couvert, O., Leguerinel, I., Postollec, F., Boulais, C., Carlin, F., Mafart, P., 2012. Modeling heat resistance of Bacillus weihenstephanensis and Bacillus licheniformis spores as function of sporulation temperature and pH. Food Microbiology 30, 29-36.

Baumgart, J., Hinrichs, M., Weber, B., Kuepper, A., 1983. Spoilage and blowing of canned green beans by Bacillus stearothermophilus. Chemie Mikrobiologie Technologie der Lebensmittel 8, 7-10.

Bender, G.R., Marquis, R.E. 1985. Spore heat resistance and specific mineralization. Applied and Environmental Microbiology 50, 1414-1421.

Bernardin, A., Pierron, D., Emerit, M., Rahmani, M.A., 2010. Les légumes en conserve et surgelés en 2010 - Bilan économique. Unilet, Paris. 27.

Bolton, L., 2001. Variety is the spice of life: a microbiological perspective. Food Safety Express 2, 17.

Bouvier, Courtois, Gantois, Niel, Richard, Sanalie, Sansoulet., 1982. Défauts et altérations des conserves - Nature et origines. 1st ed. AFNOR, Paris.

Burgess, S.A., Brooks, J.D., Rakonjac, J., Walker, K.M., Flint, S.H. 2009. The formation of spores in biofilms of Anoxybacillus flavithermus. Journal of Applied Microbiology 107, 1012-1018.

Burgess, S.A., Lindsay, D., Flint, S.H., 2010. Thermophilic bacilli and their importance in dairy processing. International Journal of Food Microbiology 144, 215-225.

Byrer, D.E., Rainey, F.A., Wiegel, J., 2000. Novel strains of Moorella thermoacetica form unusually heatresistant spores. Archives of Microbiology 174, 334-339.

Can, I.K.O., Stroot, P.G., Mackie, K.R., White, B.A. and Mackie, R.I. 2001. Characterization of two novel saccharolytic, anaerobic thermophiles, Thermoanaerobacterium polysaccharolyticum sp. nov. and 
Thermoanaerobacterium zeae sp. nov., and emendation of the genus Thermoanaerobacterium. International Journal of Systematic and Evolutionary Microbiology 51, 293-302.

Carlier, J.-P., Bedora-Faure, M., 2006. Phenotypic and genotypic characterization of some Moorella sp. strains isolated from canned foods. Systematic and Applied Microbiology 29, 581-588.

Carlier, J.-P., Bonne, I., and Bedora-Faure, M., 2006. Isolation from canned foods of a novel Thermoanaerobacter species phylogenetically related to Thermoanaerobacter mathranii (Larsen 1997): emendation of the species description and proposal of Thermoanaerobacter mathranii subsp. alimentarius subsp. nov." Anaerobe 12, 153-159

Casadei, M., Ingram, R., Skinner, R., Gaze, J., 2000. Heat resistance of Paenibacillus polymyxa in relation to $\mathrm{pH}$ and acidulants. Journal of Applied Microbiology 89, 801-806.

Chang, P.P., Lee, C.M., 1982. Spoilage bacteria in canned foods. Food Industry Research and Development Institute 65, 1-12.

Chapman, B., 2001. Anaerobic sporeforming rods. In: Group, A.I.F.M., (Ed.), Spoilage of processed Foods: Causes and diagnosis. Australian Institute of Food Science and technology Incorporated, Waterloo DC. 295-306.

Codex alimentarius, 1979. Code of hygienic pratice for low acid and acidified low acid canned foods, CAC/RCP, vol. 23 - rev 2 (1993). Codex alimentarius.

Cole, J.R., Wang, Q., Cardenas, E., Fish, J., Chai, B., Farris, R.J., Kulam-Syed-Mohideen, A.S., McGarrell, D.M., Marsh, T., Garrity, G.M., Tiedje, J.M., 2009. The Ribosomal Database Project: improved alignments and new tools for rRNA analysis. Nucleic Acids Research 37, 141-145.

CTCPA. 2012a. GBPH Fabrication de conserves de végétaux appertisés. Direction des Journaux Officiels 1 st edition - in press.

CTCPA. 2012b. GBPH Fabrication de plats cuisinés appertisés et de conserves de viande. Direction des Journaux Officiels 1 st edition $-\mathrm{n}^{\circ} 5954$, in press.

Dallyn, H., Everton, J.R., 1970. Observations on the sporicidal action of vegetable oils used in fish canning. Journal of Applied Bacteriology 33, 603-608.

De Clerck, E., Rodriguez-Diaz, M., Vanhoutte, T., Heyrman, J., Logan, N.A., De Vos, P., 2004. Anoxybacillus contaminans sp. nov. and Bacillus gelatini sp. nov., isolated from contaminated gelatin batches. International Journal of Systematic and Evolutionary Microbiology54, 941-946.

Dotzauer, C., Ehrmann, M.A., Vogel, R.F., 2002. Occurrence and detection of Thermoanaerobacterium and Thermoanaerobacter in canned food. Food Technology and Biotechnology 40, 21-26. 
Drake, H.L., Daniel, S.L., 2004. Physiology of the thermophilic acetogen Moorella thermoacetica. Research in Microbiology 155, 869-883.

Fardeau, M.L., Bonilla Salinas, M., L'Haridon, S., Jeanthon, C., Verhe, F., Cayol, J.L., Patel, B.K.C., Garcia, J.L., and Ollivier, B., 2004. Isolation from oil reservoirs of novel thermophilic anaerobes phylogenetically related to Thermoanaerobacter subterraneus: reassignment of $\mathrm{T}$. subterraneus, Thermoanaerobacter yonseiensis, Thermoanaerobacter tengcongensis and Carboxydobrachium pacificum to Caldanaerobacter subterraneus gen. nov., sp. nov., comb. nov. as four novel subspecies." International Journal of Systematic and Evolutionary Microbiology 54, 467-474

Georgescu, A.C., Bugulescu, M., 1969. Thermophilic organisms in insufficiently sterilized canned peas. Industria Alimentara 20, 251-253.

Goujon, M., McWilliam, H., Li, W., Valentin, F., Squizzato, S., Paern, J., Lopez, R., 2010. A new bioinformatics analysis tools framework at EMBL-EBI. Nucleic Acids Research 1, W695-W699

Hanlin, J.H., 1998. Spoilage of acidic products by Bacillus species. Dairy, Food and Environmental Sanitation 18, 655-659.

Hernandez, E., Feria, M.A., 1971. Typical flora of spoiled canned tomatoes. Thermal death times. Revista de Agroquimica y Tecnologia de Alimentos 11, 126-131.

Jenson, I., Jensen, N. M. H., 2001. Gram positive aerobic sporeforming rods. In: Group, A.I.F.M., (Ed.), Spoilage of processed Foods: Causes and diagnosis. Australian Institute of Food Science and Technology Incorporated, Waterloo DC. 271-294.

Kublanov, I.V., Prokofeva, M.I., Kostrikina, N.A., Kolganova, T.V., Tourova, T.P., Wiegel, J., and BonchOsmolovskaya, E.A. 2007. Thermoanaerobacterium aciditolerans sp. nov., a moderate thermoacidophile from a Kamchatka hot spring." International Journal of Systematic and Evolutionary Microbiology 57, 260264

Landry, W.L., Schwab, A.H., Lancette, G.A., 2001. Examination of Canned Foods Chapter 21A [Online]. http://www.fda.gov/Food/ScienceResearch/LaboratoryMethods/BacteriologicalAnalyticalManualBAM/ucm 109398.htm).

Lee, Y.-J., Mackie, R.I., Cann, I.K., and Wiegel, J. 2008 Description of Caldanaerobius fijiensis gen. nov., sp. nov., an inulin-degrading, ethanol-producing, thermophilic bacterium from a Fijian hot spring sediment, and reclassification of Thermoanaerobacterium polysaccharolyticum and Thermoanaerobacterium zeae as Caldanaerobius polysaccharolyticus comb. nov. and Caldanaerobius zeae comb. nov. International Journal of Systematic and Evolutionary Microbiology 58, 666-670. 
Leguerinel, I., Couvert, O., Mafart, P., 2007. Modelling the influence of the sporulation temperature upon the bacterial spore heat resistance, application to heating process calculation. International Journal of Food Microbiology 114, 100-104.

Lekogo, B.M., Coroller, L., Mathot, A.G., Mafart, P., Leguerinel, I., 2010. Modelling the influence of palmitic, palmitoleic, stearic and oleic acids on apparent heat resistance of spores of Bacillus cereus NTCC 11145 and Clostridium sporogenes Pasteur 79.3. International Journal of Food Microbiology 141, 242-247.

Liu, S.Y., Rainey, F.A., Morgan, H.W., Mayer, F., and Wiegel, J. 1996. Thermoanaerobacterium aotearoense sp. nov., a slightly acidophilic, anaerobic thermophile isolated from various hot springs in New Zealand, and emendation of the genus Thermoanaerobacterium. International Journal of Systematic of Bacteriology 46, 388-396

Mafart, P., Couvert, O., Gaillard, S., Leguerinel, I., 2002. On calculating sterility in thermal preservation methods: application of the Weibull frequency distribution model. International Journal of Food Microbiology 72, 107-113.

Matsuda, N., Komaki, M., Ichikawa, R., Gotoh, S., 1985a. Aerobic and facultative anaerobic sporeforming bacteria isolated from spoiled canned foods. Journal of Japanese Society of Food Science and Technology 32, 399-406.

Matsuda, N., Komaki, M., Ichikawa, R., Gotoh, S., 1985b. Cause of microbial spoilage of canned foods analysed during 1968-1980. Journal of Japanese Society of Food Science and Technology 32, 444-449.

Matsuda, N., Masuda, H., Komaki, M., Matsumoto, N., 1982. Thermophilic, spore-forming, strict anaerobes isolated from spoiled canned 'shiruko' and coffee containing milk. Journal of the Food Hygienic Society of Japan 23, 480-486.

Moir, C.J., Murell, W.G., Richardson, K.C., Board, P.W., 2001. Commercially sterile foods. In: Group, A.I.F.M., (Ed.), Spoilage of processed Foods: Causes and diagnosis. Australian Institute of Food Science and Technology Incorporated, Waterloo DC. 101-112.

Nazina, T.N., Tourova, T.P., Poltaraus, A.B., Novikova, E.V., Grigoryan, A.A., Ivanova, A.E., Lysenko, A.M., Petrunyaka, V.V., Osipov, G.A., Belyaev, S.S., Ivanov, M.V., 2001. Taxonomic study of aerobic thermophilic bacilli: descriptions of Geobacillus subterraneus gen. nov., sp. nov. and Geobacillus uzenensis sp. nov. from petroleum reservoirs and transfer of Bacillus stearothermophilus, Bacillus thermocatenulatus, Bacillus thermoleovorans, Bacillus kaustophilus, Bacillus thermodenitrificans to Geobacillus as the new combinations G. stearothermophilus, G. thermocatenulatus, G. thermoleovorans, 
G. kaustophilus, G. thermoglucosidasius and G. thermodenitrificans. International Journal of Systematic and Evolutionary Microbiology 51, 433-446.

Ocio, M.J., Fernandez, P., Rodrigo, F., Martinez, A., 1996. Heat resistance of Bacillus stearothermophilus spores in alginate-mushroom puree mixture. International Journal of Food Microbiology 29, 391-395.

Olson, K.E., Sorrells, K.M., 1992. Thermophilic flat sour sporeformers. In: Vanderzantz, C., Splittstoesser, D.F., (Eds.), Compendium of methods for the microbiological examination of foods, 3rd ed. American Public Health Association, Washington DC. 299-308.

Oomes, S.J., van Zuijlen, A.C., Hehenkamp, J.O., Witsenboer, H., van der Vossen, J.M., Brul, S., 2007. The characterisation of Bacillus spores occurring in the manufacturing of (low acid) canned products. International Journal of Food Microbiology 120, 85-94.

Pflug, I.J., Davidson, P.M., Holcomb, R.G., 1981. Incidence of canned food spoilage at the retail level. Journal of Food Protection 44, 682-685.

Pierce, E., Xie, G., Barabote, R.D., Saunders, E., Han, C.S., Detter, J.C., Richardson, P., Brettin, T.S. Das, A., Ljungdahl, L.G., and Ragsdale, S.W. 2008. The complete genome sequence of Moorella thermoacetica (f. Clostridium thermoaceticum Environemental Microbioliology 10, 2550-2573

Plugge, C.M., Balk, M., Zoetendal, E.G., and Stams, A.J.M., 2002 Gelria glutamica gen. nov., sp. nov., a thermophilic, obligately syntrophic, glutamate-degrading anaerobe. International Journal of Systematic and Evolutionary Microbiology 52, 401-407.

Postollec, F., Mathot, A.G., Bernard, M., Divanac'h, M.L., Pavan, S., Sohier, D., 2012. Tracking sporeforming bacteria in food: From natural biodiversity to selection by processes. International Journal of Food Microbiology 158, 1-8.

Presland, F. 2004. Microbial threats in canned foods. International Food Hygiene 15, 14-15.

Prevost, S., André, S., Remize, F., 2010. PCR Detection of thermophilic spore-forming bacteria involved in canned food spoilage. Current Microbiology 61, 525-533.

Richardson, K.C., 1972. Microbial spoilage in Australian canned foods, 1955-68. Food Technology in Australia 24, 106-107.

Röling, W.F., Kerler, J., Braster, M., Apriyantono, A., Stam, H., van Verseveld, H.W., 2001. Microorganisms with a taste for vanilla: microbial ecology of traditional Indonesian vanilla curing. Applied and Environmental Microbiology 67, 1995-2003.

Rueckert, A., Ronimus, R.S., Morgan, H.W. 2005. Rapid differentiation and enumeration of the total, viable vegetative cell and spore content of thermophilic bacilli in milk powders with reference to Anoxybacillus flavithermus. Journal of Applied Microbiology 99, 1246-1255. 
Sala, F., Abarz, P., Palop, A., Raso, J., Condon, S., 1997. Sporulation temperature and heat resistance of Bacilus subtilis at different pH values. Journal of Food Protection 58, 239-243.

Scheldeman, P., Pil, A., Herman, L., De Vos, P., Heyndrickx, M., 2005. Incidence and diversity of potentially highly heat-resistant spores isolated at dairy farms. Applied and Environmental Microbiology $71,1480-1494$.

Sevenier, V., Delannoy, S., André, S., Fach, P., Remize, F., 2012. Prevalence of Clostridium botulinum and thermophilic heat-resistant spores in raw carrots and green beans used in French canning industry. International Journal of Food Microbiology 155, 263-268.

Soh, A.L., Ralambotiana, H., Ollivier, B., Prensier, G., Tine, E., Garcia, J.L., 1991. Clostridium thermopalmarium sp. nov., a moderately thermophilic butyrate-producing bacterium isolated from palm wine in Senegal. Systemic and Applied Microbiology 14, 135-139.

Sperber, W.H., Doyle, M.P., 2009 Compendium of the microbiological spoilage of foods and beverages. New York, NY; Springer Science 367pp.

Stumbo, C.R. 1973. Thermobacteriology in food processing. 2d ed. Academic press, New York. Thompson, P.J., 1981. Thermophilic organisms involved in food spoilage: aciduric flat-sour sporeforming aerobes. Journal of Food Protection 44, 154-156.

Tucker, G., Featherstone, S., 2011. Essentials of thermal processing, Wiley-Backwell, London.

Vicini, E., 1986. A survey of the causes of microbial spoilage in tomato products during 1969-1985. Industrial Conserve 61, 338-345.

Wagner, I.D., Wiegel, J. 2008. Diversity of thermophilic anaerobes. Annals of the New York Academy of Sciences Mar, 1-43.

Waterhouse, A.M., Procter, J.B., Martin, D.M.A., Clamp, M., Barton, G.J., 2009. Jalview Version 2 - a multiple sequence alignment editor and analysis workbench. Bioinformatics 25, 1189-1191.

Weisburg, W.G., Barns, S.M., Pelletier, D.A., Lane, D.J., 1991. 16S ribosomal DNA amplification for phylogenetic study. Journal of Bacteriology 173, 697-703.

Wiegel, J., Braun, M., Gottschalk, G., 1981. Clostridium thermoautotrophicum species novum, a thermophile producing acetate from molecular hydrogen and carbon dioxide. Current Microbiology 5, 255260.

Witkowska, A.M., Hickey, D.K., Alonso-Gomez, M., Wilkinson, M.G., 2011. The microbiological quality of commercial herb and spice preparations used in the formulation of a chicken supreme ready meal and microbial survival following a simulated industrial heating process. Food Control 22, 616-625. 
Xezones, H., Segmiller, J.L., Hutchings, I.J., 1965. Processing requirements for a heat-tolerant anaerobe. Food Technology 19, 1001-1002. 
Figure 1 Phylogenic tree of the thermophilic anaerobes isolated from this study, and type strains calculated from $>1-k b$ 16S rRNA gene sequence using percent identity

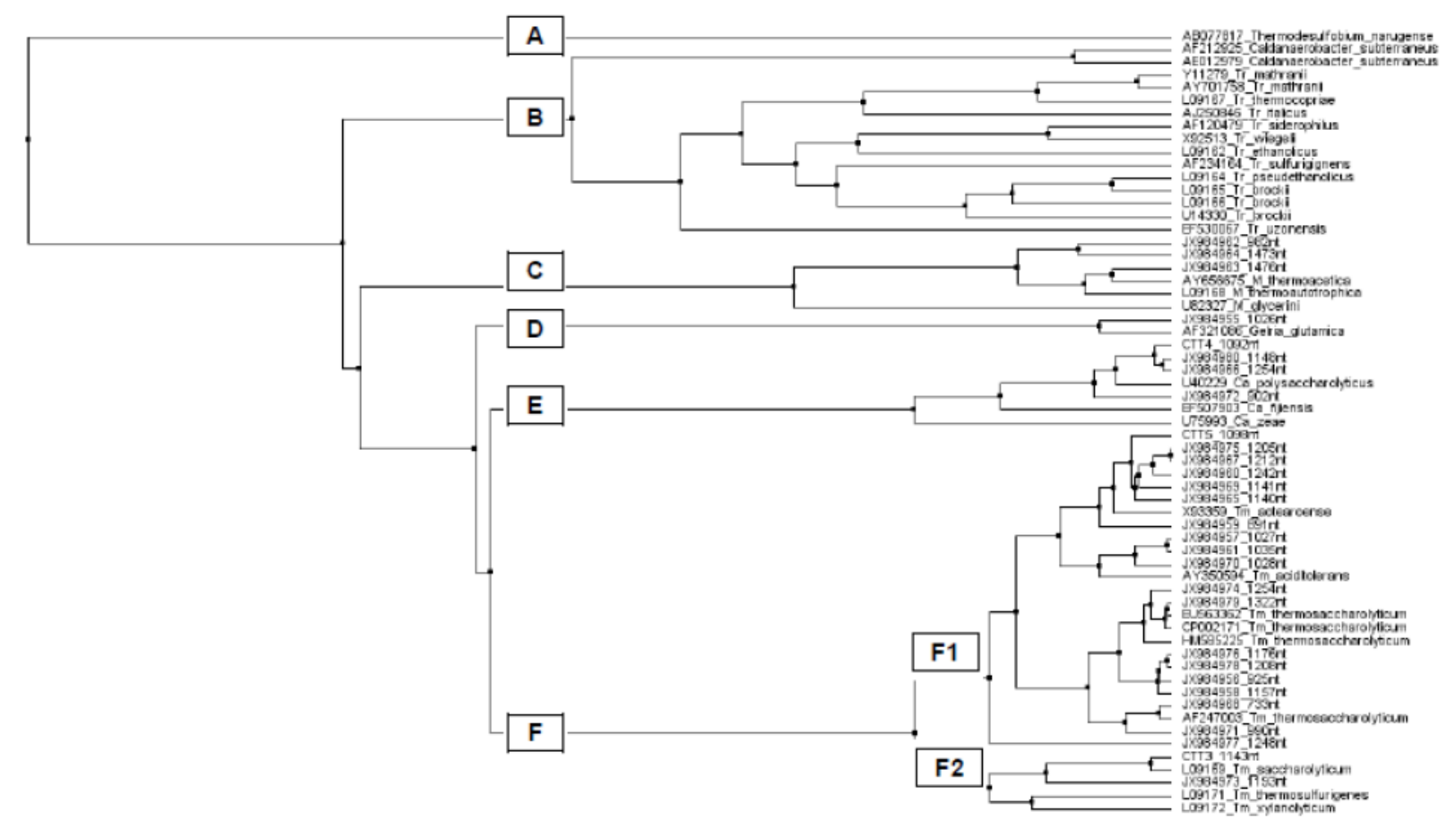


Table 1 Number of different species identified in isolates recovered from spoiled canned food samples

\begin{tabular}{ccc}
\hline $\begin{array}{c}\text { Number of } \\
\text { spoiled } \\
\text { samples }\end{array}$ & $\begin{array}{c}\text { Number of } \\
\text { isolates identified } \\
\text { from each sample }\end{array}$ & $\begin{array}{c}\text { Number of different } \\
\text { species from each } \\
\text { sample }\end{array}$ \\
\hline 76 & 2 & 1 \\
8 & 3 & 1 \\
5 & 4 & 1 \\
3 & 5 & 1 \\
7 & 2 & 2 \\
\hline
\end{tabular}


Table 2 Species and number of each species of different isolates identified in the three global food categories

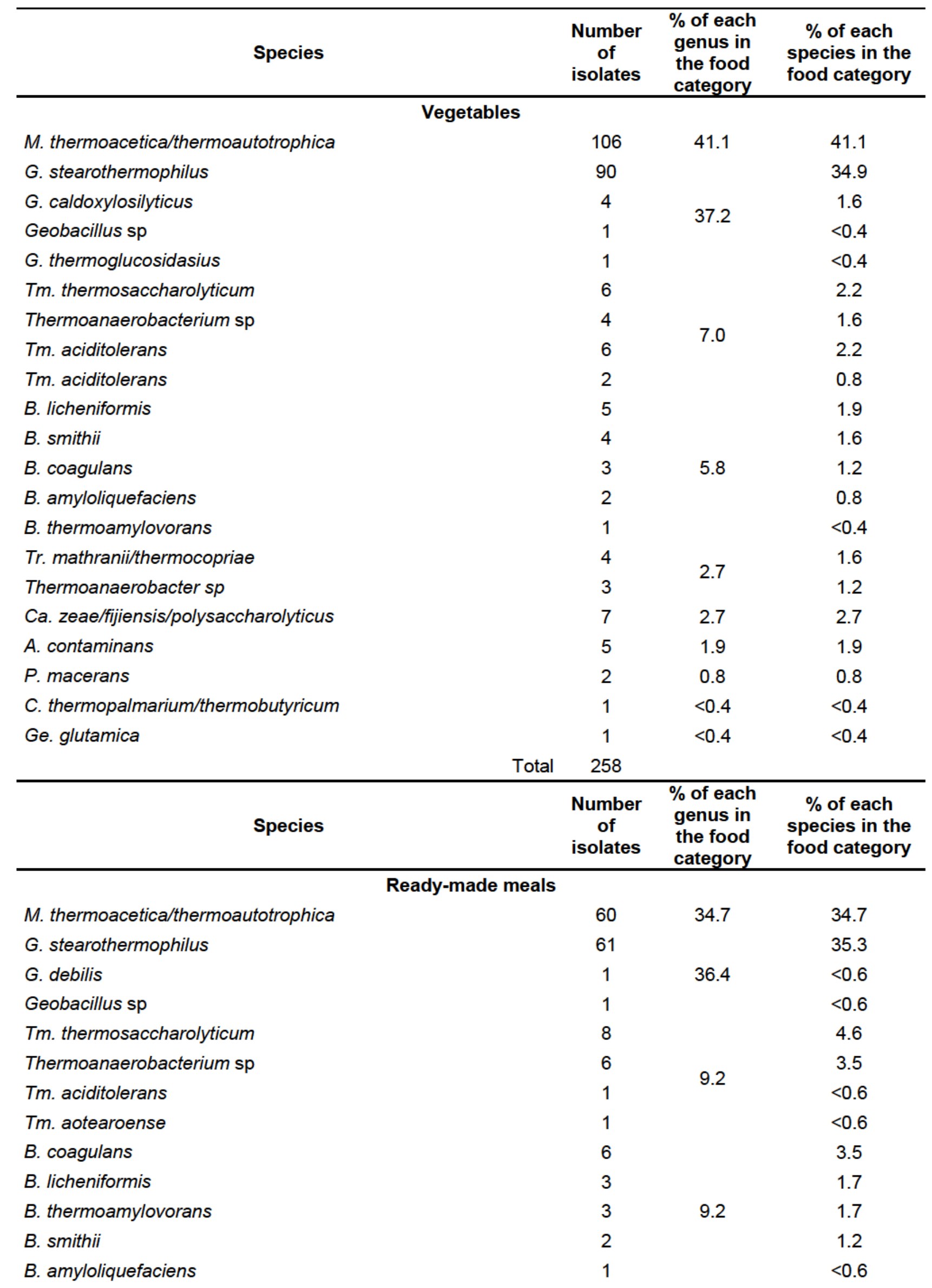


Tr. thermohydrosulfuricus

Tr. mathranii/thermocopriae

Thermoanaerobacter $\mathrm{sp}$

Ca. zeae/fijiensis/polysaccharolyticus

A. flavothermus

Total

\begin{tabular}{cccc}
\hline Species & $\begin{array}{c}\text { Number } \\
\text { of } \\
\text { isolates }\end{array}$ & $\begin{array}{c}\text { \% of each } \\
\text { genus in } \\
\text { the food } \\
\text { category }\end{array}$ & $\begin{array}{c}\text { \% of each } \\
\text { species in the } \\
\text { food category }\end{array}$ \\
\hline
\end{tabular}

Products containing fatty duck
M. thermoacetica/thermoautotrophica
G. stearothermophilus
G. pallidus

Tm. aotearoense

Tm. thermosaccharolyticum

Thermoanaerobactrium sp

B. coagulans

B. smithii

C. thermopalmarium / thermobutyricum

Thermoactinomyces $\mathrm{sp}$

\section{0}

1

1

5

5

2

4

1

11

1

31

0

0

0

6.4

3.2

(1)

5

5

\section{7}

16.1

16.1

6.4

12.9

16.1

35.5

35.5

3.2

Total

Abbreviations: A.: Anoxybacillus, B.: Bacillus, Ca.: Caldanaerobius, C.: Clostridium, Ge.: Gelria, G.:

Geobacillus, M.: Moorella, P.: Paenibacillus, Tr.: Thermoanaerobacter, Tm.: Thermoanaerobacterium 
Table 3 Spoiled food samples examined by category and occurrence of the main bacterial groups identified by canned food category, recipe and corresponding routine average $\mathrm{Fo}^{\mathrm{a}}$ used in canneries

\begin{tabular}{|c|c|c|c|c|c|c|c|c|}
\hline Product & $\begin{array}{c}\text { Number of } \\
\text { samples }\end{array}$ & $\begin{array}{l}\text { Routine } F_{o} \\
\text { (min) }\end{array}$ & $\begin{array}{c}\text { M. } \\
\text { thermoacetica / } \\
\text { thermoautotrop } \\
\text { hica }\end{array}$ & $\begin{array}{c}\text { G. } \\
\text { stearothermo } \\
\text { philus }\end{array}$ & $\begin{array}{l}\text { Thermoanaero } \\
\text { bacterium spp }\end{array}$ & B. coagulans & $\begin{array}{c}\text { C. } \\
\text { thermopalm } \\
\text { arium }\end{array}$ & $\begin{array}{c}\text { Anoxybacillus } \\
\text { spp }\end{array}$ \\
\hline \multicolumn{9}{|l|}{ Vegetables } \\
\hline Peas & 65 & $>20$ & 43 & 11 & 2 & & & \\
\hline Mixed vegetables & 31 & $>20$ & 7 & 19 & 2 & & & \\
\hline Peas - carrots & 30 & $>20$ & 23 & 4 & 1 & & 1 & \\
\hline Green beans & 27 & $5-20$ & 8 & 11 & 2 & & & \\
\hline Mushrooms & 21 & $>20$ & 8 & 5 & 3 & & & \\
\hline Vegetable soup & 14 & $>20$ & 2 & 5 & 1 & & & 5 \\
\hline Sweetcorn & 11 & $>20$ & 2 & 9 & & & & \\
\hline Spinach & 7 & $>20$ & 3 & & 1 & & & \\
\hline Flageolet beans & 5 & $5-20$ & & 4 & & & & \\
\hline White beans & 4 & $\mathrm{nc}^{\mathrm{c}}$ & & 4 & & & & \\
\hline $\begin{array}{l}\text { Other recipes } \\
\text { Subtotal }\end{array}$ & $\begin{array}{c}4 \text { or less each } \\
258\end{array}$ & nc & 0 or 1 & 3 or less each & 0 or 1 & 3 & & \\
\hline \multicolumn{9}{|c|}{$\begin{array}{l}\text { Ready-made meals } \\
\text { - Meat-based meals }\end{array}$} \\
\hline Red meat & 21 & $5-20$ & 3 & 9 & 2 & 1 & & \\
\hline Cassoulet & 17 & $5-20$ & 3 & 6 & 2 & 3 & & \\
\hline Poultry & 11 & $5-20$ & 8 & 3 & & & & \\
\hline Cottage pie & 10 & $>20$ & 7 & 1 & 1 & & & \\
\hline Sausages-lentils & 8 & $>20$ & 7 & & & & & \\
\hline Snails & 6 & $>20$ & 2 & 1 & & & & \\
\hline Couscous & 4 & $\mathrm{nc}$ & 4 & & & & & \\
\hline Other recipes $^{d}$ & $<4$ & $\mathrm{nc}$ & 2 or less each & 0 or 1 & 2 or less each & 2 & & \\
\hline $\begin{array}{l}\text { Subtotal } \\
\text { - Other types }\end{array}$ & 112 & & & & & & & \\
\hline Ravioli & 11 & $<20$ & 5 & 6 & & & & \\
\hline Quenelles & 10 & $5-20$ & & 9 & & & & \\
\hline Dairy products & 9 & $5-20$ & 1 & 6 & & & & \\
\hline Sauce & 6 & variable & 1 & 1 & 3 & & & \\
\hline
\end{tabular}




\begin{tabular}{|c|c|c|c|c|c|c|c|c|}
\hline $\begin{array}{l}\text { Other recipes }^{\mathrm{e}} \\
\text { Subtotal } \\
\text { - Seafood-based }\end{array}$ & $\begin{array}{l}<5 \\
46 \\
-\mathrm{mac}\end{array}$ & $\mathrm{nc}$ & 2 or less each & 1 or 2 & 0 & & & \\
\hline Fish soup & 4 & nc & & & & & & 3 \\
\hline $\begin{array}{l}\text { Other recipes }{ }^{\dagger} \\
\text { Subtotal }\end{array}$ & $\begin{array}{l}<3 \\
15\end{array}$ & $\mathrm{nc}$ & 1 or 0 & 3 or less each & 1 or 0 & & & \\
\hline \multicolumn{9}{|c|}{ Products containing fatty duck } \\
\hline Foie gras & 24 & $<5$ & & & 7 & 4 & 11 & \\
\hline Fat-preserved duck & 7 & $<5$ & 1 & & 5 & & & \\
\hline $\begin{array}{l}\text { Subtotal } \\
\text { Total }\end{array}$ & $\begin{array}{l}31 \\
462\end{array}$ & & 152 & 166 & 46 & 13 & 12 & 8 \\
\hline
\end{tabular}

$F_{0}$ : Sterilization value achieved at cold point of Low-Acid Canned Foods calculated with reference temperature $121,1^{\circ} \mathrm{C}$ and $\mathrm{z}=10^{\circ} \mathrm{C}$; values edited only for products analyzed more than 5 times per recipe; ${ }^{b}$ lettuce, lentils, potatoes, artichokes, chestnuts, leeks, carrots, red kidney beans, coral lentils, soy, miscellaneous;; $;$ not communicated; ${ }^{d}$ duck, terrine, meatballs, stuffed cabbage, paella, paté, cocktail sausages, miscellaneous; ${ }^{e}$ garnish, rice, miscellaneous;

f bisque, hake, fish pie, cod, miscellaneous; Abbreviations: B.: Bacillus, C.: Clostridium, G.: Geobacillus, M.: Moorella 
Table 4 Heat resistance parameters of species isolated in spoiled canned food

\begin{tabular}{|c|c|c|c|c|c|}
\hline Species & Strain & $\begin{array}{c}\text { Growth and } \\
\text { sporulation } \\
\text { temperature } \\
\left(C^{\circ}\right)\end{array}$ & $\begin{array}{c}\text { Calculated } \\
\text { temperature } \\
\left({ }^{\circ} \mathrm{C}\right) \text { for } D=10 \\
\min \end{array}$ & $\begin{array}{c}\mathbf{Z}_{\text {loglinear }} \\
\text { values ( }\end{array}$ & $\begin{array}{c}Z_{\text {Weibull }} \\
\text { values } \\
\left({ }^{\circ} \mathrm{C}\right)\end{array}$ \\
\hline M. thermoacetica & 1901058 & $\underline{55}$ & 125.9 & 7.9 & 8.0 \\
\hline M. thermoacetica & 1901053 & $\underline{55}$ & 125.6 & 8.2 & 8.6 \\
\hline M. thermoacetica & 1901020 & $\underline{55}$ & 125.3 & 6.1 & 6.5 \\
\hline G. stearothermophilus & 2804168 & $\underline{55}$ & 115.6 & 7.4 & 7.2 \\
\hline G. stearothermophilus & 2804138 & $\underline{55}$ & 114.8 & 7.6 & 7.8 \\
\hline G. stearothermophilus & 2804173 & $\underline{55}$ & 113.6 & 9.4 & 8.7 \\
\hline $\begin{array}{l}\text { Ca. zeae/figensis/ } \\
\text { polysaccharolyticus }\end{array}$ & 2503005 & $\overline{55}$ & 118.1 & 6.9 & 7.0 \\
\hline Tm. aotearoense & 2503020 & $37-\underline{55}$ & 116.5 & 7.1 & 7.7 \\
\hline Tm. aotearoense & 2501001 & $37-\overline{55}$ & 116.3 & 7.4 & 7.5 \\
\hline Tm. thermosaccharolyticum & 2506011 & $\underline{55}$ & 116.4 & 5.8 & 5.8 \\
\hline Tr. pseudothanolicus & 2510001 & $\overline{55}$ & 109.1 & 6.9 & 6.9 \\
\hline B. smithii & 3108003 & $37-55$ & 113.1 & 6.1 & 6.3 \\
\hline D. simtimi & & $\underline{37}-55$ & 110.9 & 6.7 & 6.9 \\
\hline B. smithii & 3108010 & $37-\underline{55}$ & 109.6 & 7.5 & 7.2 \\
\hline B. smithii & $3108 \quad 021$ & $37-\underline{55}$ & 105.0 & 7.5 & 7.8 \\
\hline $\begin{array}{l}\text { C. thermopalmarium/ } \\
\text { thermobutyricum }\end{array}$ & 3216001 & $\underline{55}$ & 108.3 & 6.4 & 6.2 \\
\hline Paenibacillus sp & 2911002 & $\underline{37}$ & 108.0 & 6.2 & 6.3 \\
\hline Paenibacillus $s p$ & 2901020 & $\underline{37}$ & 102.3 & 8.0 & 8.2 \\
\hline Paenibacillus $s p$ & 2901002 & $\underline{37}$ & 101.4 & 7.5 & 7.7 \\
\hline B. subtilis & 3111037 & 37 & 108.0 & 8.9 & 9.0 \\
\hline B. subtilis & 3111002 & $\overline{37}$ & 103.2 & 10.1 & 10.0 \\
\hline B. coagulans & 3105032 & $37-55$ & 106.8 & 6.2 & 6.4 \\
\hline B. coagulans & 3105018 & $37-55$ & 99.3 & 7.5 & 7.8 \\
\hline B. coagulans & 3105044 & $37-55$ & 98.6 & 8.5 & 8.4 \\
\hline B. licheniformis & 3107028 & $37-55$ & 102.4 & 8.5 & 9.2 \\
\hline \multirow{2}{*}{ B. licheniformis } & \multirow[b]{2}{*}{3107043} & $37-55$ & 97.7 & 8.0 & 6.7 \\
\hline & & $37-55$ & 97.1 & 6.7 & 6.9 \\
\hline B. licheniformis & 3107017 & $\overline{37}-55$ & 96.7 & 8.7 & 8.6 \\
\hline B. licheniformis & 3107022 & $\overline{37}-55$ & 94.9 & 8.1 & 8.1 \\
\hline C. haemolyticum & 3207002 & $\underline{37}$ & 100.6 & 8.2 & 9.2 \\
\hline C. sporogenes & 3222002 & $\overline{37}$ & 100.1 & 7.8 & 7.7 \\
\hline C. sporogenes & 3222001 & $\underline{37}$ & 99.2 & 7.4 & 7.5 \\
\hline C. sporogenes & 3213005 & $\overline{37}$ & 98.3 & 6.6 & 6.6 \\
\hline P. macerans & 2903017 & $\underline{37}$ & 99.4 & 7.8 & 7.6 \\
\hline P. macerans & 2903006 & 37 & 99.2 & 7.6 & 7.2 \\
\hline P. polymyxa & 2904003 & 37 & 90.3 & 7.8 & 8.0 \\
\hline P. polymyxa & 2904005 & 37 & 89.0 & 7.9 & 7.9 \\
\hline C. novii & 3210016 & $\underline{37}$ & 84.7 & 7.9 & 8.3 \\
\hline
\end{tabular}

a underlined : sporulation temperature; Abbreviations: A.: Anoxybacillus, B.: Bacillus, Ca.:

Caldanaerobius, C.: Clostridium, G.: Geobacillus, M.: Moorella, P.: Paenibacillus, Tr.:

Thermoanaerobacter, Tm.: Thermoanaerobacterium 


\section{Highlights:}

- 455 samples of non-stable Low-Acid Canned Food (LACF) thah showed signs of spoilage after storage at $55^{\circ} \mathrm{C}$ from 122 canneries were collected over 10 years.

- From $93 \%$ of samples only one species was isolated.

- Two species, Moorella thermoacetica/thermoautotrophica and Geobacillus stearothermophilus, represented $69 \%$ of spoilage cases.

- Different hygienic indicators are proposed for different food categories. 